\title{
PENGARUSUTAMAAN GENDER DALAM KEBIJAKAN PERUBAHAN IKLIM DI INDONESIA
}

\author{
Rusmadi \\ Universitas Islam Negeri (UIN) Walisongo Semarang \\ e-mail: rusmadi1001@yahoo.com
}

\begin{abstract}
Abstrak
Perubahan iklim menjadi persoalan serius yang dihadapi oleh masyarakat global saat ini. Persoalan yang muncul tidak hanya menyangkut keberlanjutan lingkungan, tetapi juga sosial, seperti ketidakadilan gender. Penyebanya, karena perubahan iklim dirasakan berbeda dampaknya antara laki-laki dan perempuan. Perempuan dan anak-anak adalah kelompok yang paling rentan pada saat terpapar dampak perubahan iklim. Pada saat yang sama, perempuan tidak memiliki kapasitas adaptasi yang cukup perempuan dalam menghadapi bencana iklim akibat minimnya akses, control, dan partisipasi dalam kebijakan perubahan iklim. Tulisan ini menyajikan pentingnya pengarusutamaan gender (PUG) dalam kebijakan perubahan iklim. Melalui PUG, dimaksudkan agar perempuan tidak mengalami kerentanan lebih akibat kebijakan perubahan iklim yang kurang responsif gender. Pada saat yang sama, juga akan meningkatkan kualitas kebijakan perubahan iklim, baik di tingkat nasional maupun di tingkat lokal. Semakin tinggi level kesadaran gender yang dimiliki, maka semakin tinggi pula kualitas kebijakan perubahan iklim yang dihasilkan.
\end{abstract}

Kata Kunci: perubahan iklim; kebijakan; pengarusutamaan gender (PUG)

\section{A. Pendahuluan}

Persoalan kerusakan sumberdaya alam dan lingkungan merupakan isu hangat dunia modern. Sejak abad XX, hampir seluruh penduduk dunia dihadapkan pada kenyataan munculnya kerusakan lingkungan akibat perubahan iklim seperti banjir, kekeringan, banjir, kekeringan, dan juga keberlanjutan penghidupan masyarakat. Bahkan, proliferasi kerusakan lingkungan akibat perubahan iklim telah mencapai batas-batas toleransi dan kemampuan adaptasi lingkungan karena dampaknya yang tidak lagi sebatas lokal, melainkan bersifat global. 
Pada saat paparan dampak perubahan iklim memasuki suatu wilayah yang dihuni oleh masyarakat, maka mendudukkan perubahan iklim dalam perspektif sosiologis menjadi penting, termasuk perspektif gender, karena pada kenyataanya perubahan iklim tidak hadir pada ruang kosong, melainkan hadir di tengah ruang sosiologis dan politis yang di dalamnya terdapat relasi gender. Dengan demikian, kita tidak bisa mengabaikan interplay antar keduanya (gender dan perubahan iklim). Pada konteks dimana telah terjadi relasi gender yang timpang, maka perubahan iklim akan dirasakan berbeda dampaknya antara laki-laki dan perempuan. Pada konteks dimana telah terjadi relasi gender yang timpang, maka perubahan iklim akan dirasakan berbeda dampaknya antara laki-laki dan perempuan. ${ }^{1}$ United Nation Habitat (UN Habitat), juga menyebutkan bahwa pada kondisi terpapar dampak perubahan iklim, maka dampaknya dirasakan berbeda untuk masing-masing kelompok, seperti misalnya kelompok minoritas yang terpinggirkan, laki-laki dan perempuan (relasi gender), orang tua dan anakanak. Hal ini disebabkan antara laki-laki dan perempuan memiliki peran yang berbeda di dalam keluarga, dan memiliki persepsi yang berbeda tentang bencana. ${ }^{2}$

Laporan KIARA dan Climate Justice menyebutkan bahwa pada saat terpapar dampak perubahan iklim, perempuan akan menanggung beban ganda. Di beberapa wilayah pesisir misalnya, selain bertanggungjawab pada urusan domestik, perempuan juga menjadi tumpuan dan bertanggungjawab terhadap ekonomi rumah tangga dengan membantu suami untuk memperoleh pendapatan tambahan. Perubahan cuaca ekstrim telah membuat banyak penurunan penghasilan nelayan, sehingga perempuan menjadi ikut membantu memikul beban laki-laki.Bagi perempuan di kawasan pesisir, perubahan iklim menyebabkan meningkatnya curah waktu terhadap beban pekerjaan domestik akibat hasil tangakapan ikan suaminya mengalami penurunan. Akibatnya, banyak perempuan yang kemudian harus mengerja-

${ }^{1}$ Rodenberg, B., "Climate Change Adaptation from A Gender Perspective; A Crosscuting Analysis of Development Policy Instrument," DIE Research Project Climate Change and Development, Deutsches Institut fur Entwicklungspolitik dan German Development Institute, 2009, h. 10.

${ }^{2}$ United Nations Habitat, Cities and Climate Change; Global Report on Human Settlements 2011, United Nations Human Settlements Programme, (London: Earthscan Publishing, , 2011,h. 81. 
kan pekerjaan tambahan untuk menopang ekonomi keluarga, sehingga perempuan seringkali merasakan beban ganda pada saat terpapar dampak perubahan iklim: bertanggungjawab mengurusi pekerjaan domestik rumah tangga dan sekaligus juga ikut bekerja membantu ekonomi keluarga. ${ }^{3}$

Selain bertanggungjawab pada urusan domestik dan sekaligus ikut bekerja membantu ekonomi keluarga, perempuan juga mengalami kesulitan tambahan di dalam mengerjakan pekerjaan-pekerjaan domestiknya, seperti misalnya memasak, mencuci, memandikan anak, dan membersihkan rumah. Pada beberapa kasus, saat kesulitan memasak akibat genangan rob, biasanya para ibu membeli makanan di luar, sehingga ada pengeluaran tambahan. ${ }^{4}$

Temuan Wong (2009) semakin menguatkan bahwa selain beban ganda untuk membantu ekonomi keluarga, curahan waktu untuk bekerja juga menjadi lebih lama. Wong menyebut bahwa dalam rangka bagian dari program mitigasi perubahan iklim sekala rumah tangga dengan solar home system (SHS). Sebelum menggunakan SHS, perempuan ikut bekerja membantu suami hingga pukul 20.00 malam karena penerangan yang kurang memadai. Akan tetapi, setelah adanya teknologi listrik tenaga surya beban kerja perempuan justru bertambah karena perempuan justru bekerja hingga malam hari membantu..$^{5}$

Pada saat yang sama, perempuan juga tidak memiliki kapasitas yang cukup dalam menghadapi perubahan iklim. Hal ini disebabkan karena minimnya akses perempuan dalam aspek sosial-ekonomi, dan politik yang

3Laporan KIARA, 2011, dalam Saragih, M., "Perempuan Membaca Iklim”, Jakarta: Majalah Perempuan Bergerak, Edisi II, April - Juni 2012, h. 5-6. Lihat juga laporan Climate Justice, "Perempuan dan Jejak Perubahan Iklim", edisi Januari 2011. Jakarta: Forum Masyarakat Sipil untuk Keadilan, h. 9. Lihat juga pengalaman di negara lain sebagaimana ditunjukan oleh Kevon Kerr dalam Dunn, L., (ed), "Gender, Climate Change and Disaster Risk Management," Working Paper Series Number 7, Institute of Gender and Development Studies Mona Unit, The University of the West Indies dan Friedrich Ebert Stiftung Jamaica and the Eastern Caribbean, 2013, h. 46.

${ }^{4}$ Wulansari, A., Andrea, S., Isabel, P., Risa, M., “Peningkatan Kapasitas Adaptif; Aspek Gender dalam Adaptasi Perubahan Iklim bagi Masyarakat Berpenghasilan Rendah di Kota Semarang", Indonesian-German Program-Policy Advice for Climate Change and Environment (PAKLIM-GIZ), 2011, h. 6.

${ }^{5}$ Wong. S., "Climate Change and Sustainable Technology: Re-linking Poverty, Gender, and Governance", Gender \& Development Journal Vol. 17, No. 1, 2009, h. 100. 
menyebabkan perempuan lebih rentan ketika terpapar dampak perubahan iklim. Perbedaan peran sosial antara laki-laki dan perempuan turut mempengaruhi perbedaan tingkat kerentanan di antara keduanya. Pada konteks dimana telah terdapat relasi gender yang timpang, maka perubahan iklim akan memunculkan kerentanan lebih pada kelompok gender yang termarginalkan, yakni perempuan. ${ }^{6}$

Pada konteks dimana perempuan telah menjadi kelompok yang lebih rentan akibat terpapar dampak perubahan iklim, maka diperlukan model dan strategi kebijakan perubahan iklim yang responsif gender. Sebuah kebijakan yang memposisikan perempuan secara equal dalam kontek ketahanan perubahan iklim. Hal ini dikarenakan semakin tinggi level kesadaran gender yang dimiliki oleh suatu kota, maka semakin tinggi pula kualitas kebijakan perubahan iklim di suatu kota. Sebaliknya, kegagalan memasukan perpsektif gender dalam kebijakan ketahanan perubahan iklim akan semakin menambah beban dan resiko perubahan iklim bagi kelompok yang lebih rentan.

Perubahan iklim tidak hanya menghancurkan lingkungan fisik, tetapi juga mengakibatkan penderitaan dan perjuangan panjang bagi masyarakat yang terpapar dampak, baik langsung maupun tidak langsung. Akibat terpapar dampak tersebut, penderitaan dan perjuangan yang dirasakan berbeda antara laki-laki dan perempuan. Dampak yang dirasakan oleh perempuan akibat perubahan iklim akan lebih berat dan lebih panjang. Hal ini terkadang diperparah dengan tidak dipahaminya perjuangan dan penderitaan perempuan oleh orang terdekatnya, bahkan oleh suaminya.

Dengan melihat berbagai dampak perubahan iklim kaitannya dengan kesetaraan dan keadilan gender, makadiskurus tentang perempuan dan perubahan iklim merupakandua persoalan yang tidak bisa dipisahkan. Oleh karenanya, untuk mewujudkan ketahanan perubahan iklim yang berkeadilan gender, maka dibutuhkan pengarusutamaan gender dalam kebijakan perubahan iklim. Langkah ini dilakukan dengan mengintegrasikan perspektif gender dalam perencanaan, penganggaran, pelaksanaan, pemantauan dan evaluasi, sehingga didapatkan program dan kebijakan ketahanan perubahan iklim yang responsif gender.

${ }^{6}$ Babugura, A., Gender and Climate Change: South Africa Case Study, (Southern Africa: Heinrich Boll Stiftung, 2010), h. 13. 


\section{B. Konsepsi Kesetaraan dan Keadilan Gender}

Istilah gender diperkenalkan oleh para ilmuwan sosial untuk menjelaskan perbedaan laki-laki dan perempuan yang bersifat bawaan sebagai ciptaan Tuhan dan yang bersifat kontruksi sosial dan budaya yang dipelajari dan disosialisasikan melalui proses sosial. Secara umum, gender dipahami sebagai intepretasi atau penafsiran masyarakat tentang nilai-nilai sosial, peranan, fungsi, dan tanggung jawab antara perempuan dan laki-laki yang terbentuk dalam jangka waktu lama melalui proses sosial masyarakat (habitus), sehingga menjadi suatu kebudayaan yang dapat mempengaruhi interaksi antar masyarakat. Dengan demikian, gender merupakansuatu sifat untuk mengidentifikasikan perbedaan antara laki-laki dan perempuan dari sisi sosial dan budaya, nilai dan perilaku, mentalitas dan emosi, serta faktor non biologis lainnya. ${ }^{7}$

Dengan pengertian tersebut, maka pengertian gender jelas berkaitan dengan proses keyakinan bagaimana seharusnya laki-laki dan perempuan berperan dan bertindak sesuai dengan tata nilai yang terstruktur, ketentuan sosial, dan budaya lokal. Gender bukanlah kodrat Tuhan, melainkan konstruksi manusia. Konstruksi sosial gender seringtermanifestasikan dalam keidupan masyarakat dimana perempuan dikenal sebagai makhluk yang lemah halus, lembut, mengedepankan perasaan, sedangkan laki-laki dianggap kuat, perkasa,dan mengedepankan rasionalitas.

Peran merupakan suatu tindakan yang dimiliki setiap individu, dan peran tersebut digunakan pada posisi dimana individu berada. Keberadaan individu dapat menentukan peran yang digunakan pada saat individu itu beraktivitas. Dalam pembentukan peran terdapat determinan yang dikonstruksi oleh lingkungan dimana posisi individu itu berada. Keterlibatan lingkungan memicu pada apa dan bagaimana peran tersebut digunakan.

Melihat konsep dan pemahaman seperti tersebut di atas, maka berbicara mengenai gender tidak berarti berbicara mengenai jenis kelamin (seks). Seks adalah jenis kelamin yang terdiri dari laki-laki dan perempuan yang telah ditentukan oleh Tuhan. Itulah sebabnya seks merupakan kodrat yang tidak dapat ditukar atau diubah, dan berlaku sejak dahulu kala,

${ }^{7}$ Reeves, H. dan Baden, S., Gender and Development: Concepts and Definitions, (UK: BRIDGE (Development - Gender), Institute of Development Studies University of Sussex, 2000), h. 30 . 
sekarang dan berlaku selamanya. Secara umum, seks digunakan untuk mengidentifikasi perbedaan laki-laki dan perempuan dari segi anatomi biologis dan komposisi kimia dalam tubuh laki-laki dan perempuan. ${ }^{8}$

Dengan pengertian tersebut, maka seks dapat dikatakan sebagai perbedaan laki-laki dan perempuan sebagai makhluk yang secara kodrati memiliki fungsi-fungsi organisme yang berbeda. Dalam arti perbedaan jenis kelamin, seks mengandung pengertian laki-laki dan perempuan terpisah secara biologis, yang berarti perempuan memiliki hormon, postur tubuh dan alat reproduksi yang berbeda dengan laki-laki. Secara biologis alat-alat biologis tersebut melekat pada lelaki dan perempuan selamanya, fungsinya tidak dapat dipertukarkan, secara permanen tidak berubah dan merupakan ketentuan biologi atau Tuhan/kodrat. Guna lebih memperjelas uraian mengenai gender dan seks, Tabel 1 berikut ini adalahperbedaan antar keduanya berserta contohnyamasing-masing sebagaimana digambarkan oleh Puspitawati, 2012:9

Tabel 1.

Perbedaan Jenis Kelamin dan Gender

\begin{tabular}{|c|c|c|}
\hline No. & $\begin{array}{l}\text { Jenis Kelamin (Seks) dan } \\
\text { Contoh Kodrati }\end{array}$ & Gender dan Contoh Bukan Kodrati \\
\hline 1. & $\begin{array}{l}\text { Peran reproduksi kesehatan berlaku } \\
\text { sepanjang masa, dan ditentukan oleh } \\
\text { Tuhan sebagai kodrat }\end{array}$ & $\begin{array}{l}\text { Peran sosial bergantung pada waktu } \\
\text { dan keadaan, dan ditentukan oleh } \\
\text { manusia (kontruksi sosial) dan bukan } \\
\text { sebagai kodrat }\end{array}$ \\
\hline 2. & $\begin{array}{l}\text { Pada aspek organ biologis khususnya } \\
\text { pada bagian alat-alat reproduksi, per- } \\
\text { empuan memiliki alat reproduksi } \\
\text { seperti rahim menstruasi, hamil, } \\
\text { melahirkan, dan menyusui. Sementara } \\
\text { laki-laki memiliki penis dan } \\
\text { spermatozoa }\end{array}$ & $\begin{array}{l}\text { Menyangkut perbedaan peran, fungsi, } \\
\text { dan tanggungjawab laki-laki dan } \\
\text { perempuan sebagai hasil kontruksi } \\
\text { sosial, misalnya laki-laki mencari } \\
\text { nafkah dan mengurusi urusan publik. } \\
\text { Sedangkan perempuan bertanggung- } \\
\text { jawab pada masalah rumah tangga } \\
\text { (urusan domestik) }\end{array}$ \\
\hline
\end{tabular}
2013), h. 3-4. 


\begin{tabular}{|c|c|c|}
\hline No. & $\begin{array}{l}\text { Jenis Kelamin (Seks) dan } \\
\text { Contoh Kodrati }\end{array}$ & Gender dan Contoh Bukan Kodrati \\
\hline 3. & $\begin{array}{l}\text { Peran reproduksi tidak dapat dirubah, } \\
\text { sekali menjadi perempuan dan } \\
\text { memiliki rahim, maka selamanya akan } \\
\text { begitu. Laki-laki memiliki penis dan } \\
\text { membuahi, maka selama akan begitu. }\end{array}$ & $\begin{array}{l}\text { Peran sosial dapat berubah. Peran istri } \\
\text { sebagai ibu rumah tangga dapat ber- } \\
\text { ubah menjadi pekerja mencari nafkah. } \\
\text { Atau urusan public dan domestik } \\
\text { dapat diurus secara bersama-sama } \\
\text { oleh laki-laki dan perempuan. }\end{array}$ \\
\hline 4. & $\begin{array}{l}\text { Peran reproduksi tidak dapat } \\
\text { ditukarkan. Tidak mungkin peran laki- } \\
\text { laki kemudian melahirkan dan } \\
\text { menyusui, dan sebaliknya peran } \\
\text { perempuan membuahi. }\end{array}$ & $\begin{array}{l}\text { Peran sosial dapat dipertukarkan. } \\
\text { Untuk saat-saat tertentu, bisa saja } \\
\text { suami dalam keadaan menganggur } \\
\text { sehingga tinggal di rumah dan meng- } \\
\text { urus rumah tangga, dan sebaliknya istri } \\
\text { bekerja di sektor publik. }\end{array}$ \\
\hline
\end{tabular}

Sumber: Puspitawati, 2012: 3-4, dimodifikasi.

Dari berbagai uraian tersebut di atas, maka jelas bahwa gender merupakan konstruksi sosial.Ia sangat bergantung pada ruang dan waktu dimana konstruksi tersebut dibangun. Sejarah pembedaan antara laki-laki dan perempuan terjadi melalui proses sosialisasi, penguatan dan konstruksi sosial kultural, keagamaan, bahkan melalui kekuasaan negara. Melalui proses yang panjang, gender lambat laun menjadi seolah-olah kodrat Tuhan, atau ketentuan biologis yang tidak dapat diubah lagi. Akibatnya, gender mempengaruhi keyakinan manusia serta budaya masyarakat tentang bagaimana lelaki dan perempuan berpikir dan bertindak sesuai dengan ketentuan sosial tersebut. Dengan kata lain, masyarakat sebagai kelompoklah yang menciptakan perilaku gender berdasarkan apa yang dianggap sebagai keharusan bagi laki-laki dan perempuan.

Keyakinan terhadap pembagian tersebut kemudian diwariskan dari satu generasi ke generasi selanjutnya, penuh dengan proses, negosiasi, resistensi maupun dominasi. Akhirnya, lama kelamaan pembagian keyakinan gender tersebut dianggap alamiah, normal dan kodrat. Karena merupakan konstruksi sosial, maka gender berbeda satu sama lain, bergantung ruang dan waktu dimana gender dikonstruksikan.Suatu peraturan perundangundangan maupun kebijakan juga dapat menimbulkan terjadinya berbagai ketidakadilan gender karena telah berakar dalam adat, norma ataupun struktur masyarakat. Bentuk-bentuk ketidakadilan gender misalnya termanifestasikan dalam berbagai bentuk ketidakadilan, seperti misalnya; 
marginalisasi, subordinasi, stereotype/pelabelan negatif sekaligus perlakuan diskriminatif, kekerasan terhadap perempuan, beban kerja lebih banyak dan lebih panjang. ${ }^{10}$

Gender, dengan demikian, sangat terkait dengan peranan yang dilakukan laki-laki dan perempuan sesuai status, budaya dan struktur masyarakatnya. Konstruksi peranan pada akhirnya memunculkan peran yang harus dimainkan oleh individu, baik peran produktif, peran reproduktif, maupun peran pengelolaan masyarakat dan politik. Fakih (1996), sebagaimana dikutip Rochmayanto dan Kurniasih menjelaskan bahwa peran produktif merupakan peranan yang terkait dengan memperoleh pendapatan ekonomi seperti kegiatan bekerja, baik di sektor formal maupun informal. Sementara peran reproduktif merupakan peranan yang terkait dengan tanggung jawab pengasuhan anak dan tugas-tugas domestik lain untuk menjamin kelangsungan reproduksi seperti melahirkan, memelihara dan mengasuh anak, mengambil air, memasak, mencuci, membersihkan rumah, memperbaiki baju dan lain-lain. Sedangkan peran pengelolaan masyarakat dan politik merupakan semua peran di tengah masyarakat, baik dalam konteks sosial maupun dalam konteks politik. Peranan dalam konteks politik meliputi aktivitas-aktivitasdi tengah masyarakat sebagai kepanjangan peran reproduktif yang bersifat sukarela dan tanpa upah. Sementara peranan dalam konteks politik meliputi peranan dalam pengorganisasian masyarakat pada tingkat formal secara politik untuk meningkatkan kekuasaan atau status tertentu..$^{11}$

Pembicaraan mengenai kesetaraan dan keadilan gender tidaklah berarti berbicara mengenai perempuan atau laki-laki saja dalam konteks jenis kelamin, melainkan berbicara mengenai hal paling dasar, yakni hak asasi manusia dan ketidakadilan sosial. Oleh sebab itu, berbicara mengenai isuisu gender selalu meletakkan kesetaraan dan keadilan gender sebagai isu utama, mengingat gender pada umumnya erat kaitannya dengan relasi antara laki-laki dan perempuan, baik pada aspek sosial-politik, ekonomi, maupun budaya.

\footnotetext{
${ }^{10}$ Marzuki, A.G., "Gender dalam Perpektif Kesetaraan dan Keadilan", Jurnal Musawa, Vol. 3, No. 2, 2011, h. 211-213.

${ }^{11}$ Rochmayanto, Y., dan Kurniasih, P., "Peranan Gender dalam Adaptasi Perubahan Iklim pada Ekosistem Pegunungan di Kabupaten Solok Sumatera Barat," Jurnal Analisis Kebijakan Kehutanan, Vol. 10 No. 3, Desember 2013, h. 205.
} 


\section{Dampak Perubahan Iklim dalam Perspektif Gender}

Sebagaimana telah disinggung pada pendahuluan, bahwa perubahan iklim akan dirasakan berbeda dampaknya antara kelompok laki-laki dan perempuan, akibat adanya relasi gender yang timpang di dalam kehidupan masyarakat yang terpapar dampak. Artinya, relasi gender turut menentukan bagaimana paparan dampak tersebut dirasakan oleh laki-laki dan perempuan. Bagi kelompok yang terpinggirkan dalam relasi sosialnya (misalnya perempuan), maka perubahan iklim dirasa lebih berat. ${ }^{12}$

Terjadinyaketimpangan gender telah menyebabkan kerentanan yang lebih bagi kelompok perempuan, dan di saat yang sama perempuan juga menjadi kelompok yang tidak memiliki kapasitas cukup untuk menghadapi dampak perubahan iklim. Minimnya kapasitas tersebut dikarenakan minimnya akses perempuan terhadap informasi perubahan iklim. Padahal, kapasitas yang dimiliki sangat menentukan langkah-langkah adaptasi perubahan iklim. Semakin minim kapasitas adaptasi yang dimiliki maka semakin rentan terhadap dampak perubahan iklim. Minimnya akses terhadap informasi tersebut secara tidak langsung disebabkan oleh minimnya peran perempuan dalam ruang publik. Kondisi ini menyebabkan perempuan lebih rentan ketika terpapar dampak perubahan iklim..$^{13}$

Babugura (2010) menyebut bahwa peran sosial laki-laki dan perempuan serta akses terhadap sumberdaya, baik sumberdaya alam, sumber daya ekonomi, sumber daya manusia, dan sumber daya sosial akan mempengaruhi kapasitas adaptasi masyarakat terhadap perubahan iklim. ${ }^{14}$ Sementara Nelson (2011) menyebut bahwa terjadinya ketimpangan gender telah menyebabkan kerentanan yang lebih bagi kelompok perempuan, karena tidak memiliki kapasitas cukup untuk menghadapi dampak perubahan iklim. ${ }^{15}$ Minimnya kapasitas adaptasi perempuan terhadap per-

${ }^{12}$ UN Women Watch, Women, Gender Equality and Climate Change, 2009, h. 1. Lihat juga Rahman, Md. S., "Climate Change, Disaster and Gender Vulnerability: A Study on Two Divisions of Bangladesh", American Journal of Human Ecology Vol. 2, No. 2, 2013, h. 79-80.

${ }^{13}$ Nelson, V., Gender, Generations, Social Protection \& Climate Change; A Thematic Review, (London, UK: Overseas Development Institute, 2011), h. 2 dan 45. Lihat juga tulisan Alber, G., "Gender, Cities and Climate Change; Thematic Report Prepared for Cities and Climate Change". Global Report on Human Settlements, 2011, h. 16.

${ }^{14}$ Babugura, A., Gender and Climate Change: South Africa Case Study, (Southern Africa: Heinrich Boll Stiftung, 2010), h.13.

${ }^{15}$ Nelson, V., Gender, Generations, Social Protection \& Climate Change..., h. 45. 
ubahan iklim juga disebabkan minimnya partisipasi perempuan dalam perumusan kebijakan perubahan iklim. Padahal, kapasitas yang dimiliki sangat menentukan langkah-langkah adaptasi perubahan iklim. Semakin minim kapasitas adaptasi yang dimiliki maka semakin rentan terhadap dampak perubahan iklim. Kondisi-kondisi tersebut menyebabkan perubahan iklim menjadi tidak netral gender. ${ }^{16}$

Akibat adanya peran sosial yang bias gender, pada akhirnya berdampak pada minimnya akses kelompok perempuan terhadap sumberdaya, baik sumberdaya alam, sumberdaya ekonomi, maupun sumberdaya politik. Hal ini kemudian menyebabkan kapasitas adaptasi yang dimiliki oleh kelompok perempuan untuk menghadapi perubahan iklim cukup minim. Akibatnya, pada saat terpapar dampak perubahan iklim, perempuan menjadi kelompok yang memiliki beban ganda, perempuan lebih banyak menjadi korban, dan perempuan menjadi kelompok yang lebih rentan rentan. Selengkapnya adalah sebagaimana uraian berikut:

\section{a. Beban Ganda Perempuan Akibat Dampak Perubahan Iklim}

Selain perempuan lebih rentan, perempuan juga memiliki beban ganda akibat dampak perubahan iklim. Hal ini dikarenakan dampak perubahan iklim dapat menyulitkan ekonomi rumah tangga, maka perempuan turut membantu suami untuk memperoleh pendapatan tambahan. Pada masyarakat di pesisir yang menggantungkan hidupnya dari alam, perubahan cuaca ekstrim membuat banyak nelayan tidak dapat melaut dan hasil tangkapan ikan menurun. Pada kondisi semacam ini perempuanlah penebus kekurangan itu. ${ }^{17}$ Selain bertanggung jawab membantu ekonomi keluarga, perempuan juga mengalami kesulitan melaksanakan tugas-tugas domestiknya pada saat terpapar dampak perubahan iklim, seperti misalnya memasak, mencuci piring, memandikan anak, dan membersikan rumah. ${ }^{18}$

\footnotetext{
${ }^{16}$ Dankelman, dalam Masika, R (ed), Gender, Development, and Climate Change, (UK: Oxfam GB, 2002), h. 24-26. Lihat juga Rodenberg, B., 2009, Rodenberg, B., “Climate Change Adaptation from A Gender Perspective....," h. 10.

${ }^{17}$ Climate Justice, "Perempuan dan Jejak Perubahan Iklim", h. 9. Lihat juga Kevon Kerr dalam Dunn, L., (ed), “Gender, Climate Change and Disaster Risk Management,” h. 46.

${ }^{18}$ Wulansari, A., Andrea, S., Isabel, P., Risa, M., "Peningkatan Kapasitas Adaptif; Aspek Gender dalam Adaptasi Perubahan Iklim ....," h. 6.
} 


\section{b. Perempuan Lebih Rentan Akibat Dampak Perubahan Iklim}

Perbedaan peran sosial perempuan dan perbedaan kapasitas perempuan menyebabkan perempuan menjadi kelompok yang lebih rentan dibandingkan laki-laki pada saat terpapar dampak perubahan iklim. Hal ini disebabkan minimnya peran yang diberikan kepada perempuan dalam aspek sosial-ekonomi, dan politik, sehingga kelompok perempuan tidak memiliki kapasitas yang cukup untuk menghadapi perubahan iklim. Beberapa studi menyebutkan bahwa kondisi sosial-budaya masyarakat dan juga kebijakan-kebijakan publik justru lebih banyak membatasi perempuan. Kerentanan sangat bergantung dengan besaran dan jenis paparan dampak negatif dari perubahan iklim, dan apakah masyarakat yang terdampak tersebut dapat menghindari dampak tersebut atau tidak. Kapasitas untuk beradaptasi dengan dampak perubahan iklim sangat bergantung pada tingkat pendapatan masyarakat, jumlah modal atau asset untuk penghidupan (livelihoods capital and asset), pendidikan dan pengetahuan masyarakat yang terdampak. Padahal pada semua aspek tersebut telah terjadi ketimpangan gender. ${ }^{19}$

\section{c. Perempuan Lebih Banyak Menjadi Korban}

Pada beberapa wilayah, kejadian-kejadian bencana yang terkait dengan perubahan iklim, perempuan adalah kelompok yang paling banyak menjadi korban, misalnya terkait dengan munculnya dampak banjir dan kekeringan. Sementara berdasarkan survei kerentanan kelompok manusia yang menderita akibat perubahan iklim dalam MDGs, perempuan dan anak adalah kelompok yang paling banyak menjadi korban perubahan iklim. ${ }^{20}$ Pada banyak negara di Asia, seperti India, Nepal, Pakistan, Bangladesh, dan China, bencana tersebut telah memakan korban perempuan lebih banyak. Banyak perempuan yang menjadi garda depan dan menjadi korban kekeringan dan banjir. ${ }^{21}$ Di Banglades, pada tahun 1991 misalnya,

${ }^{19}$ United Nations Habitat, Cities and Climate Change; Global Report on Human Settlements 2011, h. 81-82. Lihat juga Babugura, A., Gender and Climate Change: South Africa Case Study, h. 5 dan 16.

${ }^{20}$ Lihat laporan Majalah Perempuan Bergerak, " Perempuan Menjadi Korban Perubahan Iklim", h. 13-14.

${ }^{21}$ Nellemann, C., Verma, R., and Hislop, L. (eds), "Women at the Frontline of Climate Change: Gender Risks and Hopes. A Rapid Response Assessment". United Nations Environment Programme, GRID-Arendal, 2011,h. 15-17. 
bencana banjir telah menewaskan 71 orang per 1.000 korban jiwa, sementara laki-laki hanya 15 orang per 1.000 korban jiwa. Di Indonesia, kejadian Tsunami di Aceh tahun 2004 telah memakan banyak korban jiwa. Dari jumlah korban yang meninggal dunia, sebanyak $70 \%$ adalah perempuan. ${ }^{22}$

\section{Implementasi Pengarusutamaan Gender dalam Kebijakan Perubahan Iklim}

Sebelum memahami lebih dalam mengenai implementasi pengarusutamaan gender dalam kebijakan perubahan iklim, perlu kiranya terlebih dulu melihat perkembangan paradigma studi gender. Sebagaimana mafhum diketahui bahwa studi gender, tidak lepas dari dinamika konsep relasi antara perempuan dan pembangunan dimana terdapat setidaknya 4 (empat) paradigma studi gender. Pertama, paradigm Women in Development (WID) atau pendekatan peningkatan peran wanita dalam pembangunan. Kedua, paradigma Women and Development (WAD). Ketiga, paradigma Gender and Development (GAD), dan Keempat, paradigma Gender Mainstreaming atau Pengarusutamaan Gender (PUG).

Fakih (2011) sebagaimana dikutip Emiyanti (2015) menjelaskan bahwa diletakkannya pengetahuan WID dalam diskursus pembangunan adalah suatu privilage, dan bukan karena keadaan nyata akibat proses under development. Dengan kata lain, paradigma WID memiliki strategi "meningkatkan peran wanita" atau "melibatkan kaum wanita dalam pembangunan". Dengan demikian, paradigma WID menginginkan perempuan harus dibawa ke dalam proses modernisasi. Strategi ini menjadi dominan di tahun 1970-an ketika PBB menetapkannya sebagai strategi pembangunan secara global. Sejak saat itulah, negara-negara Dunia Ketiga mulai mengembangkan Kementerian Peranan Wanita. ${ }^{23}$

Setelah paradigma WID dilaksanakan selama satu dekade, sejak dekade pertama pembangunan perempuan $\mathrm{PBB}$, ternyata berbagai program

\footnotetext{
${ }^{22}$ Tickamyer, A. R., Kusujiarti, S., Wornell, E. J.,2013, Gender Justice, Climate Change, and Sustainable Development in Indonesia, Globalization, Development and Security in Asia, Vol-IV, h. 82.

${ }^{23}$ Emiyanti, S., "Pengarusutamaan Gender sebagai Setrategi Mutakhir Gerakan Perempuan," Jurnal Antropologi Sosial Budaya ETNOVISI, Vol. 1, No. 2. Oktober 2015, h. 72.
} 
peningkatan peran perempuan dianggap gagal untuk mengubah nasib berjuta-juta kaum perempuan dan ternyata banyak program pembangunan mempunyai dampak berbeda bagi kaum laki-laki dan kaum perempuan. Pada saat itu mulailah timbul kesadaran baru bahwa paradigma WID telah gagal membebaskan perempuan dari diskriminasi dan ketidakadilan. Atas dasar itu pula suatu paradigma baru yang tidak menyalahkan korban ketidakadilan dan yang terlalu memfokuskan terhadap kaum perempuan mulai dikaji. ${ }^{24}$

Salah satu yang dianggap menjadi persoalan terletak bukan pada kaum perempuannya, melainkan pada ideologi yang dianut oleh baik laki-laki maupun perempuan yang sangat berpengaruh dalam kebijakan dan pelaksanaan pembangunan. Mereka melihat bahwa mengintegrasikan perempuan ke dalam pembangunan dalam sistim yang bersifat patriarki adalah tidak akan berhasil, karena perempuan tetap berada dalam sistim yang tersubordinasi. Untuk itu mereka banyak mengusung proyek-proyek yang bersifat "hanya perempuan", yang secara hati-hati dikonstruksi untuk memproteksi kepentingan perempuan dari dominasi patriarki. Keinginan tersebut kemudian melairkan paradigm Women and Development (WAD). Paradigma WAD menekankan pada kekhasan pengetahuan, pekerjaan, tujuan dan tanggungjawab perempuan yang berbeda dengan laki-laki. Oleh karena itu, paradigma WAD menuntut pengakuan terhadap kekhasan ini sehingga perempuan dapat berperan secara khusus dan tersendiri dalam proses pembangunan. Misalnya; karena diyakini bahwa perempuan di Afrika memegang peran penting dalam produksi pertanian, maka pemberian kredit pertanian harus diberikan melalui mereka. ${ }^{25}$

Meskipun perspektif WAD telah menawarkan koreksi penting terhadap perspektif WID, akan tetapi pada perkembangannya belum cukup mampu mengurangi terjadinya bias gender dalam pembangunan. Akibat dari kebijakan pembangunan yang bias gender, banyak program pembangunan telah mempunyai dampak yang berbeda terhadap kaum laki-laki dan perempuan. Atas dasar itu kemudian muncullah paradigm Gender and Development (GAD), yakni suatu paradigma yang sepenuhnya meng-

${ }^{24}$ Fakih, M., Runtuhnya Teori Pembangunan dan Globalisasi, (Yogyakarta: Pustaka Pelajar, 2011), h. 169.

${ }^{25}$ Ibid., h. 170 . 
gunakan analisis gender. Paradigma GAD dianggap sebagai suatu alternatif baru setelah WID dan WAD. ${ }^{26}$

Paradigma GAD menyuarakan suatu sintesa isu-isu ekonomi politik yang materialistis dan isu feminis radikal terhadap ideologi patriarki. Paradigma GAD berargumentasi bahwa status perempuan dalam masyarakat dipengaruhi secara kuat oleh kondisi material kehidupan mereka dan oleh posisi mereka dalam sistim ekonomi nasional, regional dan global, termasuk juga dalam komunitas maupun rumah tangga. Lebih lanjut, kondisi materialistik perempuan dan pola kewenangan patriarki dijaga oleh norma-norma dan nilai-nilai yang ada, yang membedakan peran dan tanggung jawab perempuan dan laki-laki dalam masyarakat. Paradigma GAD melihat bahwa relasi gender dilihat sebagai kunci penentu dari keberadaan posisi perempuan dalam masyarakat. Relasi gender dipahami sebagai suatu konstruksi sosial, bukan kodrati. ${ }^{27}$ Paradigma GAD ini kemudian berhasil melahirkan konvensi pengapusan segala bentuk diskriminasi terhadap perempuan atau yang dikenal dengan Konvensi CEDAW. Pemerintah Indonesia kemudian meratifikasi konvensi tersebut melalui Undang-Undang No 7 Tahun 1984 tentang Penghapusan Diskriminasi terhadap Kaum Perempuan..$^{28}$

Akan tetapi, pada perjalanannya, upaya penghapusan diskriminasi terhadap kaum perempuan tidak berjalan memuaskan. PBB kemudian mengangkat perspektif gender agar lebih tegas di dalam implementasinya pada negara. Pada tahun 1995 diselenggarakan Konferensi PBB ke-4 di Beijing. Pada konferensi Beijing ini dikeluarkan Beijing Platform for Action (BPFA) sebagai suatu strategi yang kemudian dikenal dengan Gender Mainstreaming atau Pengarusutamaan Gender (PUG). Paradigma PUG menfokuskan pada peran negara. Oleh karenanya, paradigma PUG hendak mengembangkan kebijakan yang mengintegrasikan pengalaman dan masalah perempuan dan laki-laki ke dalam perencanaan, pelaksanaan, pemantauan, dan evaluasi terhadap kebijakan dan program. Pemerintah Indonesia telah meratifikasi konvensi Beijing tersebut melalui Inpres No. 9

${ }^{26}$ Ibid.

${ }^{27}$ Emiyanti, S., "Pengarusutamaan Gender sebagai Setrategi Mutakhir Gerakan Perempuan," h. 73.

${ }^{28} \mathrm{Ibid}, \mathrm{h} .74$. 
Tahun 2000 tentang Pengarusutamaan Gender dalam Pembangunan Nasional. ${ }^{29}$

Pengarusutamaan gender memang membutuhkan perhatian kepada perspektif gender sebagai bagian integral dari kegiatan di semua kebijakan dan program, dalam arti bahwa harus ada pelibatan perempuan dan lakilaki dalam suatu proses pengambilan kebijakan dan program, termasuk di dalamnya dilibatkan pada pelaksanaan dan pemantauan suatu kebijakan dan program tersebut. Pengarusutamaan gender juga berarti terus mengurangi kesenjangan yang ada dan mempromosikan kesetaraan dan keadilan gender. Pengarusutamaan gender dan pemberdayaan perempuan bukanlah konsep yang saling bersaing satu sama lain, melainkan keduanya saling melengkapi. Hal ini dikarenakan pengarusutamaan gender harus dilakukan dengan cara pemberdayaan perempuan. ${ }^{30}$

Pengarusutamaan gender (gender mainstreaming) didefinisikan sebagai

"The public policy concept of assessing the different implications for women and men of any planned policy action, including legislation and programmes, in all areas and levels. Mainstreaming essentially offers a pluralistic approach that values the diversity among both women and men". ${ }^{31}$

Selain itu, pengarusutamaan gender juga dipahami sebagai:

"The process of assessing the implications for women and men of any planned action, including legislation, policies and programmes, in all areas and at all levels, and as a strategy for making women's as well as men's concerns and experiences an integral dimension of the design, implementation, monitoring and evaluation of policies and programmes in all political, economic and social spheres so that women and men benefit equally and inequality is not perpetuated. The ultimate goal is to achieve gender equality". 32

\section{${ }^{29} \mathrm{Ibid}$.}

${ }^{30}$ Osagi. 2001. "Important Concepts Underlying Gender Mainstreaming" dalam www.un.org/womenwatch/osagi/pdf/factsheet2.pdf (Diakses pada 22 Oktober 2012), h. 1-2.

${ }^{31}$ Booth dan Bennett, 2002 dalam Mainlay, J., Su F. T., Mainstreaming Gender and Climate Change in Nepal, London: IIED Climate Change Working Paper (2), 2012, h. 5.

32UNECOSOC Resolution 1997/2 dalam Alber, G., “Gender, Cities and Climate Change; Thematic Report Prepared for Cities and Climate Change". h. 24. 
Dengan definisi sebagaimana tersebut di atas, maka pengarusutamaan gender dalam konteks kebijakan perubahan iklim didefinisikan sebagai strategi untuk mencapai kesetaraan dan keadilan gender dengan cara mengintegrasikan dimensi gender ke dalam perencanaan, penyusunan, pelaksanaan, pemantauan, dan evaluasi atas kebijakan perubahan iklim, baik mitigasi maupun adaptasi. Dengan demikian, pengarusutamaan gender memerlukan seperangkat analisis gender yang mencoba menganalisis perubahan relasi antara laki-laki dan perempuan, serta perbedaan keduanya dalam kehidupan sosial (social role). Hal ini dikarenakan aktivitas yang menopang penghidupan masyarakat akan sangat terpengaruh oleh adanya dampak perubahan iklim.

Pada konteks Indonesia, kebijakan yang responsif gender telah direspon oleh pemerintah melalui Instruksi Presiden (Inpres) No. 9 Tahun 2000 tentang Pengarusutamaan Gender (PUG) dalam Pembangunan Nasional. PUG yang dimaksudkan adalah melakukan seluruh proses pembangunan mulai dari penyusunan perencanaan, pelaksanaan, pemantauan dan evaluasi yang berperspektif gender dengan melibatkan peran serta warga negara, baik laki-laki maupun perempuan. Implementasi pengarusutamaan gender dilakukan memasukan 4 (empat) indikator pengarusutamaan gender, yakni akses, partisipasi, kontrol, dan manfaat. Selengkapnya dapat dilihat sebagaimana diagram berikut ini:

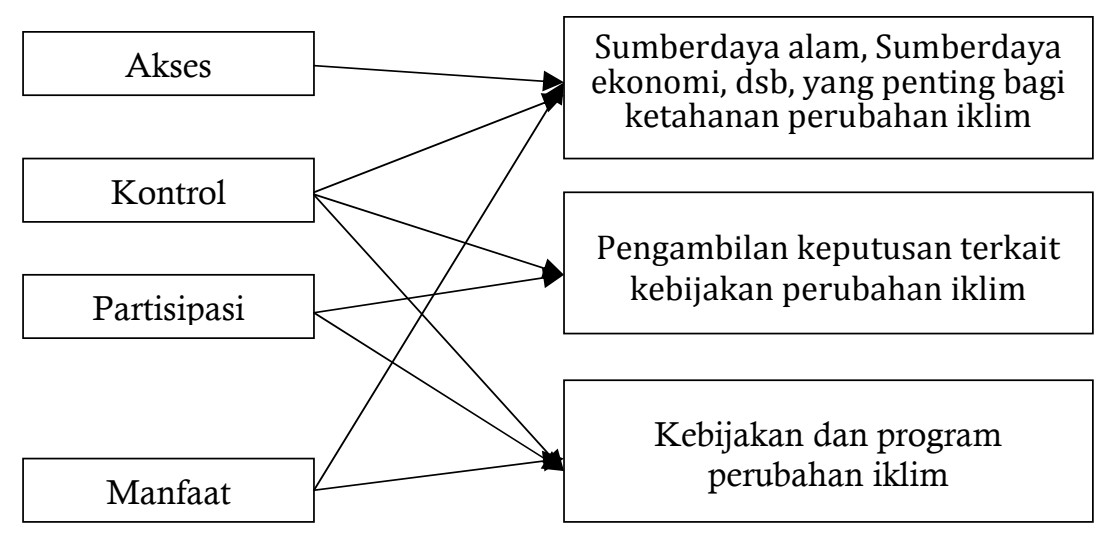

Diagram 1. Impelemntasi Pengarusutamaan Gender 
Perlunya optimalisasi langkah-langkah pengarusutamaan gender sebagaimana tersebut di atas dimaksudkan agar perempuan tidak mengalami kerentanan lebih akibat dampak dan sekaligus juga akibat kebijakan perubahan iklim yang kurang responsif gender.Pada saat yang sama, dengan pengarusutamaan gender maka pemerintah juga dapat bekerja lebih efisien dan efektif dalam memproduksi kebijakan, program, kegiatan yang adil dan responsif gender, serta Kebijakan dan pelayanan publik serta program dan perundang-undangan yang adil dan responsif gender akan membuahkan manfaat yang adil bagi semua masyarakat, baik perempuan dan laki-laki. Hal ini dikarenakan pengarusutamaan gender merupakan upaya untuk menegakkan hak-hak perempuan dan laki-laki atas kesempatan yang sama, pengakuan yang samadan pengahargaan yang sama. Pada akhirnya, dengan implementasi pengarusutamaan gender maka akan meningkatkan kualitas kebijakan perubahan iklim, baik di tingkat nasional maupun di tingkat lokal. Semakin tinggi level kesadaran gender yang dimiliki, maka semakin tinggi pula kualitas kebijakan perubahan iklim yang dihasilkan.

\section{Kesimpulan}

Berdasarkan uraian sebagaimana tersebut di atas maka dapat disimpulkan bahwa perubahan iklim tidaklah netral gender. Hal ini dikarenakan perubahan iklim akandirasakan berbeda dampaknya antara laki-laki dan perempuan. Perempuan dan anak-anak adalah kelompok yang paling rentan pada saat terpapar dampak, akibat adanya beban ganda pada saat terpapar dampak perubahan iklim, perempuan lebih banyak menjadi korban, dan minimnya kapasitas adaptasi perubahan iklim. Minimnya kapasitas adaptasi disebabkan oleh minimnya akses, kontrol, dan partisipasi perempuan dalam perumusan kebijakan-kebijakan perubahan iklim, sehingga isu-isu tentang gender dalam konteks perubahan iklim kurang mendapat tempat. Untuk meningkatkan ketahanan perubahan iklim, maka diperlukan pengarusutamaan gender dalam kebijakan perubahan iklim dengan mengintegrasikan perpsketif gender dalam perencanaan, penganggaran, pelaksanaan, pemantauan dan evaluasi dengan memperhatikan kebutuhan, aspirasi, potensi, dan pengalaman perempuan dalam konteks perubahan iklim. Implementasi pengarusutamaan gender dimaksudkan agar perempuan tidak mengalami kerentanan lebih akibat dampak dan juga sekaligus akibat kebijakan perubahan iklim yang kurang responsif gender. 
Pada saat yang sama, juga akan meningkatkan kualitas kebijakan perubahan iklim, baik di tingkat nasional maupun di tingkat lokal. Karena semakin tinggi level kesadaran gender yang dimiliki, maka semakin tinggi pula kualitas kebijakan perubahan iklim yang dihasilkan.[]

\section{Daftar Pustaka}

Alber, G., Gender, "Cities and Climate Change; Thematic Report Prepared for Cities and Climate Change". Global Report on Human Settlements 2011.

Babugura, A., Gender and Climate Change: South Africa Case Study, Southern Africa: Heinrich Boll Stiftung, 2010.

Climate Justice, "Perempuan dan Jejak Perubahan Iklim", edisi Januari 2011. Jakarta: Forum Masyarakat Sipil untuk Keadilan, 2011.

Dunn, L., (ed), "Gender, Climate Change and Disaster Risk Management", Working Paper Series Number 7, Institute of Gender and Development Studies Mona Unit, The University of the West Indies dan Friedrich Ebert Stiftung Jamaica and the Eastern Caribbean, 2013.

Emiyanti, S., "Pengarusutamaan Gender sebagai Setrategi Mutakhir Gerakan Perempuan'. Jumal Antropologi Sosial Budaya ETNOVISI, Vol. 1, No. 2. Oktober 2015.

Fakih, M., Runtuhnya Teori Pembangunan dan Globalisasi, Yogyakarta: Pustaka Pelajar, 2011.

Mainlay, J., Su F. T., "Mainstreaming Gender and Climate Change in Nepal", London: IIED Climate Change Working Paper (2), 2012,

Majalah Perempuan Bergerak, "Perempuan Menjadi Korban Perubahan Iklim," Edisi II April - Juni 2012.

Marzuki, A.G., Gender dalam Perpektif Kesetaraan dan Keadilan, Jumal Musawa, Vol. 3, No. 2, 2011.

Masika, R (ed), Gender, Development, and Climate Change, UK: Oxfam GB, 2002.

Nellemann, C., Verma, R., and Hislop, L. (eds), "Women at the Frontline of Climate Change: Gender Risks and Hopes. A Rapid Response Assessment. United Nations Environment Programme," GRID-Arendal, 2011.

Nelson, V., Gender, Generations, Social Protection \& Climate Change; A Thematic Review, London, UK: Overseas Development Institute, 2011. 
Osagi. "Important Concepts Underlying Gender Mainstreaming", 2001, dalam www.un.org/womenwatch/osagi/pdf/factsheet2.pdf (Diakses pada 22 Oktober 2012).

Puspitawati, H., Gender dan Keluarga; Konsep dan Realitas di Indonesia, Bogor: PIPB Press, 2013.

Rahman, Md. S., "Climate Change, Disaster and Gender Vulnerability: A Study on Two Divisions of Bangladesh", American Joumal of Human Ecology Vol. 2, No. 2, 2013.

Reeves, H. dan Baden, S., Gender and Development: Concepts and Definitions. UK: BRIDGE (Development-Gender), Institute of Development Studies University of Sussex, 2000.

Rochmayanto, Y., dan Kurniasih, P., "Peranan Gender dalam Adaptasi Perubahan Iklim pada Ekosistem Pegunungan di Kabupaten Solok Sumatera Barat", Jurnal Analisis Kebijakan Kehutanan, Vol. 10 No. 3, Desember 2013.

Rodenberg, B., "Climate Change Adaptation from A Gender Perspective; A Cross-cuting Analysis of Development Policy Instrument, DIE Research Project Climate Change and Development", Deutsches Institut fur Entwicklungspolitik dan German Development Institute, 2009.

Saragih, M., "Perempuan Membaca Iklim", Majalah Perempuan Bergerak, Jakarta, Edisi II, April - Juni 2012.

Tickamyer, A. R., Kusujiarti, S., Wornell, E. J., "Gender Justice, Climate Change, and Sustainable Development in Indonesia", Globalization, Development and Security in Asia, Vol-IV, 2013.

UN WomenWatch, "Women, Gender Equality and Climate Change", 2009.

United Nations HABITAT, "Cities and Climate Change; Global Report on Human Settlements 2011", United Nations Human Settlements Programme, London: Earthscan Publishing, 2011.

Wong. S., Climate Change and Sustainable Technology: Re-linking Poverty, Gender, and Governance. Gender \& Development Journal Vol. 17, No. 1. , 2009.

Wulansari, A., Andrea, S., Isabel, P., Risa, M., Peningkatan Kapasitas Adaptif; Aspek Gender dalam Adaptasi Perubahan Iklim bagi Masyarakat Berpenghasilan Rendah di Kota Semarang, Indonesian-German Program Policy Advice for Climate Change and Environment (PAKLIM-GIZ), 2011. 
